\title{
Primary immunodeficiency investigation in patients during and after hospitalization in a pediatric Intensive Care Unit
}

\author{
Investigação de imunodeficiências primárias em pacientes durante e após hospitalização em uma \\ Unidade de Terapia Intensiva pediátrica
}

Investigación de inmunodeficiencias primarias en pacientes durante y después de la hospitalización en una Unidad de Terapia Intensiva pediátrica

Érica Suavinho', Ana Carolina R. de Nápolis¹, Gesmar Rodrigues S. Segundo²

\section{ABSTRACT}

Objective: To analyze whether the patients with severe infections, admitted in the Pediatric Intensive Care Unit of the Hospital de Clínicas of the Universidade Federal de Uberlândia, underwent the active screening for primary immunodeficiencies (PID).

Methods: Retrospective study that assessed the data records of patients with any severe infections admitted in the Pediatric Intensive Care Unit, covering a period from January 2011 to January 2012, in order to confirm if they performed an initial investigation for PID with blood count and immunoglobulin dosage.

Results: In the studied period, 53 children were hospitalized with severe infections in the Pediatric Intensive Care Unit, and only in seven $(13.2 \%)$ the initial investigation of PID was performed. Among these patients, 3/7 (42.8\%) showed quantitative alterations in immunoglobulin $\mathrm{G}$ (IgG) levels, $1 / 7$ (14.3\%) had the diagnosis of cyclic neutropenia, and $1 / 7(14.3 \%)$ presented thrombocytopenia and a final diagnosis of Wiskott-Aldrich syndrome. Therefore, the PID diagnosis was confirmed in 5/7 (71.4\%) of the patients.

Conclusions: The investigation of PID in patients with severe infections has not been routinely performed in the Pediatric Intensive Care Unit. Our findings suggest the necessity of performing PID investigation in this group of patients.

Key-words: infection; allergy and immunology; child; immunoglobulins; intensive care; pneumonia.
RESUMO

Objetivo: Verificar se os pacientes internados na Unidade de Terapia Intensiva Pediátrica do Hospital de Clínicas da Universidade Federal de Uberlândia com infecções graves foram submetidos à busca ativa de imunodeficiências primárias (IDP).

Métodos: Estudo observacional retrospectivo realizado na Unidade de Terapia Intensiva Pediátrica. Incluíram-se pacientes com diagnóstico de qualquer infecção grave admitidos de janeiro de 2011 a janeiro de 2012. Verificou-se se os pacientes admitidos realizaram a investigação inicial para IDP com hemograma e dosagem de imunoglobulinas.

Resultados: No período estudado, 53 crianças foram internadas com infecções graves, sendo que apenas sete $(13,2 \%)$ realizaram investigação inicial para IDP. Desses pacientes, 3/7 $(42,8 \%)$ tinham alterações quantitativas dos níveis de imunoglobulina $\mathrm{G}$ (IgG), 1/7 (14,3\%) apresentou diagnóstico de neutropenia cíclica e 1/7 (14,3\%), plaquetopenia e diagnóstico de síndrome de Wiskott-Aldrich. Portanto, o diagnóstico de IDP foi confirmado em 5/7 (71,4\%) dos pacientes.

Conclusões: A investigação de IDP em pacientes com infecções graves não tem sido realizada rotineiramente na Unidade de Terapia Intensiva Pediátrica. Nossos achados sugerem a necessidade de investigar as IDP nesse grupo de pacientes.

Palavras-chave: infecção; alergia e imunologia; criança; imunoglobulinas; terapia intensiva; pneumonia.

Endereço para correspondência:

Gesmar Rodrigues S. Segundo

Avenida Pará, 1.720

CEP 38400-902 - Uberlândia/MG

E-mail: gesmar@famed.ufu.br

Conflito de interesse: nada a declarar

Recebido em: 28/6/2013

Aprovado em: 10/9/2013 


\section{RESUMEN}

Objetivo: Verificar si los pacientes internados en la Unidad de Terapia Intensiva Pediátrica del Hospital de Clínicas de la Universidad Federal de Uberlândia (Brasil) con infecciones graves fueron sometidos a la busca activa de inmunodeficiencias primarias (IDP).

Métodos: Estudio transversal retrospectivo realizado en la Unidad de Terapia Intensiva Pediátrica. Se incluyeron pacientes con diagnóstico de cualquier infección grave admitidos de enero de 2011 a enero de 2012. Se verificó si los pacientes admitidos realizaron la investigación inicial para IDP con hemograma y dosis de inmunoglobulinas.

Resultados: En el periodo estudiado, 53 niños fueron internados con infecciones graves, siendo que solamente siete $(13,2 \%)$ realizaron investigación inicial para IDP. De esos pacientes, $3 / 7$ (42,8\%) tenían alteraciones cuantitativas de los niveles de inmunoglobulinas G (IgG), 1/7 (14,3\%) presentó diagnóstico de neutropenia cíclica y $1 / 7$ (14,3\%), plaquetopenia y diagnóstico de síndrome de WiskottAldrich. Por lo tanto, el diagnóstico de IDP se confirmó en $5 / 7(71,4 \%)$ de los pacientes.

Conclusiones: La investigación de IDP en pacientes con infecciones graves no viene siendo realizada de manera rutinera en la Unidad de Terapia Intensiva Pediátrica. Nuestros hallazgos confirman la necesidad de investigar las IDP en ese grupo de pacientes.

Palabras clave: infección; alergia e inmunología; niño; inmunoglobulinas; terapia intensiva; neumonía.

\section{Introduction}

Primary immunodeficiencies (PIDs) are rare diseases considered in isolation; however, they comprise a set of over 200 different changes already described and have an estimated prevalence of 1:2,000 live births ${ }^{(1)}$. In general, PIDs are monogenic, hereditary diseases, which cause immunological changes and can express increased susceptibility to certain types of infections, tumors, or autoimmune diseases ${ }^{(1,2)}$.

Patients with PIDs present, in general, recurrent and/or more severe infections than those usually observed for each age group ${ }^{(3)}$. In previous surveys conducted by the Primary Immunodeficiency Foundation, the infections most associated to subsequent diagnosis of PIDs in patients in the United States were pneumonia, acute otitis media, sinusitis, tracheobronchitis, and acute diarrhea, which are common in childhood $^{(4)}$. In this sense, the Jeffrey Modell Foundation, along with other American institutions, formulated warning signs to draw attention for the need to investigate a possible immune deficiency in this group of patients ${ }^{(5)}$.

In Brazil, these warning signs underwent an adaption to local realities, in a joint effort of the Brazilian Society of Pediatrics and the Brazilian Association of Allergy and Immunology, with the emergence of the Brazilian Group for Immunodeficiency, which became responsible for disseminating these alert signals in the medical environment. Among the warning signs (Chart 1), there is an episode of severe systemic infection (meningitis, osteoarthritis, and sepsis) ${ }^{(6,7)}$.

The aim of this study was to determine whether patients with serious infections, admitted to the Pediatric Intensive Care Unit of Hospital de Clínicas, Federal University of Uberlândia, have been regularly subjected to active screening for PIDs on admission or during the follow-up.

\section{Method}

Retrospective observational study conducted in the Pediatric Intensive Care Unit (PICU) of Hospital de Clínicas, Federal University of Uberlândia in 2012. It included patients diagnosed with any serious infection admitted to the PICU from January 2011 to January 2012, and excluded those with a history of hospitalization for initial trauma or postoperative for other causes. The data were obtained through the yearbook of admissions of the PICU and records were analyzed until the period of data collection, which took place from March to May 2012, i.e., at least two months from the initial date of admission.

Chart 1 - The 10 Warning Signs for Primary Immunodeficiency in Children adapted to Brazil

\section{Two or more episodes of pneumonia in the previous year}

2. Four or more episodes of otitis in the previous year

3. Recurrent stomatitis and moniliasis for over 2 months

4. Recurrent abscesses or ecthyma

5. One episode of severe systemic infection (meningitis, osteoarthritis, septicemia)

6. Recurrent intestinal infections/chronic diarrhea

7. Severe asthma, collagen vascular disease, or autoimmune disease

8. Adverse effects to BCG and/or mycobacterial infection

9. Clinical phenotype suggestive of syndrome associated with immunodeficiency

10. Family history of immunodeficiency

Source: Adapted from Jeffrey Modell Foundation and the American Red Cross by the Brazilian Society of Pediatrics and the Brazilian Association of Allergy and Immunology 
The data verified on the patient's manual and digital records comprised information on age, sex, primary diagnosis, and secondary diagnosis during hospitalization, presence of comorbidities, history of previous infections, tests performed on admission and, subsequently, hospitalization. Within the tests, it was considered as an initial investigation for PIDs the performance of complete blood count (CBC) and serum immunoglobulin $\mathrm{G}, \mathrm{A}$, and $\mathrm{M}$ together.

We used a convenience sample, composed of all patients who met the inclusion criteria in the year proposed for the study. Results were expressed by means of descriptive statistics. The study was approved by the Research Ethics Committee of Universidade Federal de Uberlândia.

Table 1 - Characteristics. diagnosis on admission and previous infections in patients with serious infections treated at the Pediatric Intensive Care Unit of Hospital de Clínicas. Universidade Federal de Uberlândia

\begin{tabular}{lr}
\hline & \multicolumn{1}{c}{ Patients } \\
\hline Age (months) & $36(1-144)$ \\
Male sex & $26(49.0 \%)$ \\
Deaths during hospitalization & $4(7.5 \%)$ \\
History of recurrent infections & $19(35.8 \%)$ \\
Immunological research with CBC and & $7(13.2 \%)$ \\
immunoglobulin check & \\
Normal & $2(28.5 \%)$ \\
Abnormal & $5(71.5 \%)$ \\
Diagnosis on admission & \\
Pneumonia & $22(41.5 \%)$ \\
Sepsis/septic shock & $16(30.1 \%)$ \\
Meningitis/encephalitis & $7(13.2 \%)$ \\
Skin infections & $5(9.4 \%)$ \\
Gastroenteritis & $3(5.6 \%)$ \\
Myocarditis/pericarditis & $2(3.7 \%)$ \\
Abscesses & $2(3.7 \%)$ \\
Types of recurrent infections ${ }^{* *}$ & \\
Pneumonia & $11(57.9 \%)$ \\
Acute otitis media & $4(21.0 \%)$ \\
Sepsis & $4(21.0 \%)$ \\
Gastroenteritis & $3(15.8 \%)$ \\
Meningitis & $3(15.8 \%)$ \\
Urinary tract infection & $2(10.5 \%)$ \\
Skin infections & $2(10.5 \%)$ \\
\hline
\end{tabular}

*Median (range); **Described in the medical records of 19 patients; the remaining 34 records did not mention previous infections

\section{Results}

From January 2011 to January 2012, 53 children were admitted to the PICU involved in the study with primary diagnosis of some form of severe infectious. The mean age was 4.3 years (ranging from 0.08 to 12 years) and 26 patients (49\%) were male. Of this total, four (7.5\%) died during hospitalization.

The most prevalent diagnoses associated with hospitalization were pneumonia in 22 (41.5\%), followed by sepsis/septic shock in $16(30.1 \%)$, and others less prevalent (Table 1). Nineteen $(35.8 \%)$ patients contained a history of recurrent infections such as pneumonia, otitis, and sinusitis in their records (Table 1).

Among the 53 patients, only seven (13.2\%) underwent initial screening for PIDs through the association of immunoglobulin A ( $\operatorname{Ig} A)$, immunoglobulin $\mathrm{G}$ ( $\operatorname{IgG}$ ), immunoglobulin $\mathrm{M}(\operatorname{Ig} \mathrm{M})$, and immunoglobulin $\mathrm{E}(\operatorname{IgE})$ checks. One $(14.3 \%)$ of the seven patients presented changes in neutrophils, which subsequently confirmed the diagnosis of cyclic neutropenia. One (14.3\%) presented thrombocytopenia ( 44.000 platelets $/ \mathrm{mm}^{3}$ ) with abnormal platelet size and high $\operatorname{IgE}(1.760 \mathrm{UI} / \mathrm{mL})$ associated with a complicated generalized eczema, diagnosed with Wiskott-Aldrich syndrome. Another three (42.8\%) of the seven patients studied showed reduced levels of $\operatorname{IgG}$, and in one of them, the values of $\operatorname{IgA}$ and $\operatorname{IgM}$ were also reduced to the levels of agammaglobulinemia. Two patients with low IgG levels alone were diagnosed with transient hypogammaglobulinemia of infancy, and the patient with global deficit of antibodies is one of the four patients who died during hospitalization, not having the chance to complete the investigation. The levels of antibodies were demonstrated in graphical representation of immunoglobulins by age (Figure 1 ). Among the seven patients with initial screening, only two $(28.5 \%)$ presented normal blood count and serum immunoglobulin for the age range.

\section{Discussion}

Infections are the main manifestations of PIDs. They may occur in a recurring basis and, thus, the patient has a much larger number of infections that the average for his age group, or may present more severe infections, with increased risk $^{(8)}$. The patients with PIDs may also present with PIDs infections caused by unusual pathogens ${ }^{(9)}$. 
The more severe infections in patients with PIDs occur by the deficit in combating pathogens that multiply fast, and, often require the use of antibiotics in larger doses or for longer periods than usual, to have an adequate clinical response ${ }^{(10)}$. In the present study, the most prevalent initial infection responsible for ICU admission was pneumonia, given equivalent surveys of general infections in children with PIDs ${ }^{(11)}$. Another interesting fact is that most patients already had records of recurrent infections, which should warn for the diagnosis of primary immunodeficiency.

To improve medical knowledge about PIDs, the warning signs were developed, which have been disseminated in the medical community through lectures, cards, and posters, and the use of social media to draw attention to the need to perform the screening of these patients, whose diagnosis can provide a more effective treatment of the disease, reducing the number of infections and hence, the morbidity and mortality ${ }^{(12)}$.

The PICUs have, as part of their target audience, patients with serious infections, precisely one of the indicative signs of PIDs and that suggest the immunological investigation. Nevertheless, even in a reference institution, such as that here presented, which is a tertiary hospital with regional demand and linked to the area of education, the screening of patients has not been performed routinely, as analyzed by the present study.

In a previously published epidemiological survey on PIDs in Latin America, $53.2 \%$ of registered PIDs were predominantly antibody defects and $22.6 \%$ were well-defined genetic syndromes that occur with immunodeficiencies ${ }^{(3)}$. In the present study, in the seven cases investigated, four had diagnostic confirmation of PIDs and another had low levels of all classes of antibodies, being highly suggestive of agammaglobulinemia with distribution compatible with the mentioned survey.

It is important to mention that $70 \%$ of the assessed patients were diagnosed by simple tests provided by the Brazilian public Unified Health System and available to almost all medical institutions, such as those performed in this study. The immunological investigation in patients with PIDs is individualized according to the signs and symptoms and must be performed in stages, according to the findings in each subject ${ }^{(2)}$. Thus, even if the blood count and immunoglobulins have shown normal results in two other patients investigated, other humoral changes cannot be excluded, such as complement changes or qualitative deficit of antibodies, or even cellular changes, such as qualitative for phagocytes or lymphocytes, or other more specific. These

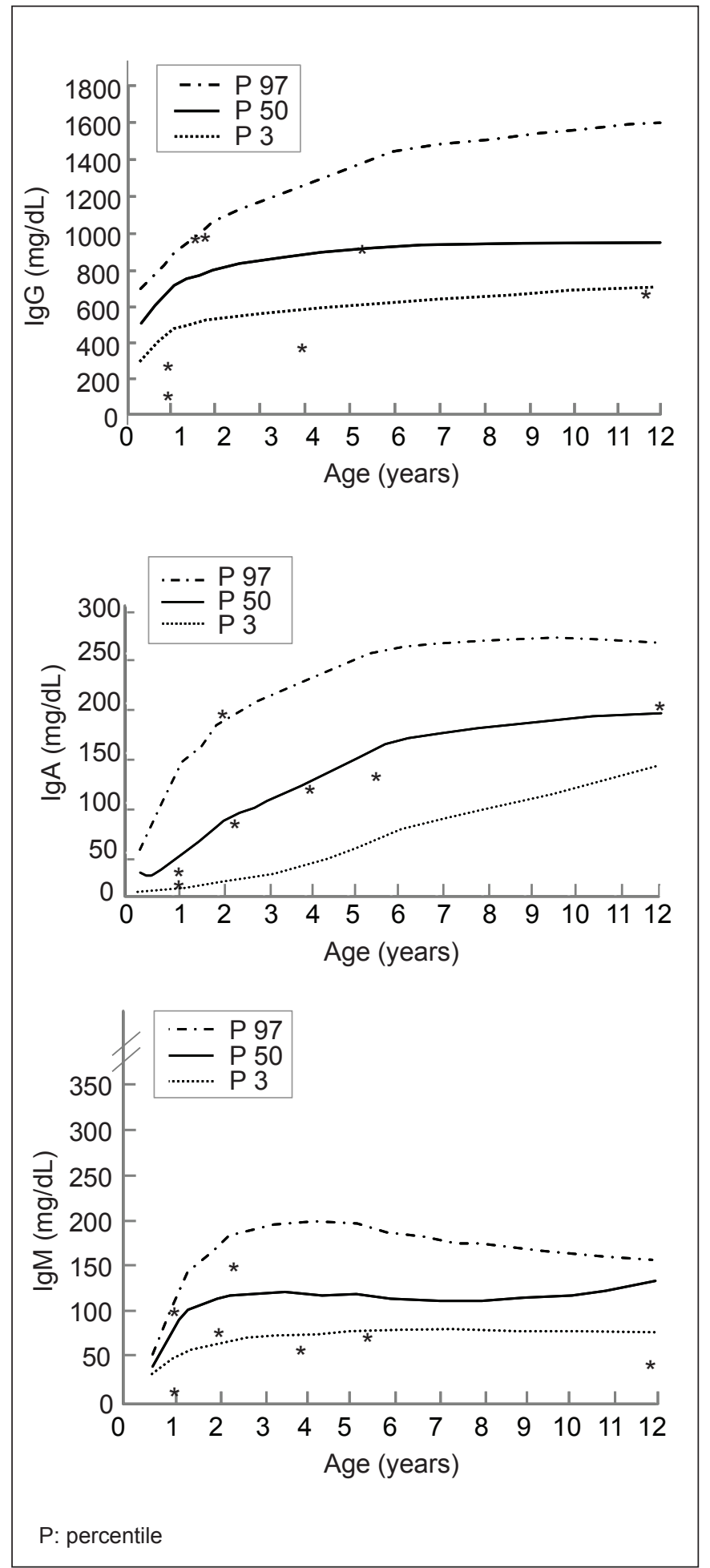

Figure 1 - Levels of antibodies of immunoglobulin class $G$ ( $\lg G)$, immunoglobulin $A(\lg A)$, and immunoglobulin $M(\lg M)$ in patients with serious infections, admitted at the pediatric ICU of Hospital de Clínicas, Universidade Federal de Uberlândia, who conducted the initial investigation for primary immunodeficiencies. Reference curves of antibodies IgG, IgA, and IgM in the Brazilian population from Fujimura $\mathrm{MD}^{13}$. 
patients should be referred for further evaluation in immunology research centers, which require greater dissemination among pediatricians so that patients can be referred, investigated, and followed-up accordingly.

The present study has limitations due to the retrospective data collection, with analysis depending on the completion of the medical records of each patient. A multicenter prospective cohort would present more reliable data about the actual need for investigation of these patients.

\section{References}

1. Geha RS, Notarangelo LD, Casanova JL, Chapel H, Conley ME, Fischer A et al. Primary immunodeficiency diseases: an update from the International Union of Immunological Societies Primary Immunodeficiency Diseases Classification Committee. J Allergy Clin Immunol 2007;120:776-94.

2. Al-Herz W, Bousfiha A, Casanova JL, Chapel H, Puck JM, Roifman CM et al. Primary immunodeficiency diseases: an update on the classification from the international union of immunological societies expert committee for primary immunodeficiency. Front Immunol 2011;2:1-26.

3. Leiva LE, Zelazco M, Oleastro M, Carneiro-Sampaio M, Condino-Neto A, Costa-Carvalho BT et al. Primary immunodeficiency diseases in Latin America: the second report of the LAGID registry. J Clin Immunol 2007;27:101-8.

4. Immune Deficiency Foundation [homepage on the Internet]. Primary Immune Deficiency Diseases in America - The first national survey of patients and specialists. Immune Deficiency Foundation [cited 2013 Feb]. Available from: http://primaryimmune.org/idf-publications/?aid=1262\&pid=275\&sa=1

5. Primary Immunodeficiency Resource Center [homepage on the Internet]. New York: The Jefrey Modell Foundation 10 Warning Signs for Primary Imunodeficiencies [cited 2013 Feb 01]. Available from: http://www.info4pi.org/ aboutPI/pdf/General10WarningSignsFINAL.pdf

6. Segundo GR, Fernades KP. Impaired polysaccharide responsiveness: case reports. Rev Bras Alerg Imunopatol 2009;32:194-8.
It can be concluded that, even in a PICU of a tertiary care hospital that has a reference center for the diagnosis and treatment of PIDs, the investigation of immunodeficiencies has not been performed as a routine. Given the number of patients with abnormalities among those investigated, it is necessary to develop strategies for continuing medical education in the pediatric intensive care teams so that the investigation of PIDs becomes a routine examination in patients with serious infections.

7. Imunopediatria [homepage on the Internet]. São Paulo. Os 10 sinais de alerta para imunodeficiências primárias modificados pela Sociedade Brasileira de Pediatria e Associação Brasileira de Alergia e Imunologia [cited 2013 Feb 01]. Available from: http://www.imunopediatria.org.br/ download/10sinais.pdf

8. Conley ME, Notarangelo LD, Etzioni A. Diagnostic criteria for primary immunodeficiencies. Representing PAGID (Pan-American Group for Immunodeficiency) and ESID (European Society for Immunodeficiencies). Clin Immunol 1999;3:190-7.

9. Silva GB, Fernandes KP, Segundo GR. Common variable immunodeficiency and isosporiasis: first report case. Rev Soc Bras Med Trop 2012;45:768-9.

10. Buckley $\mathrm{RH}$. Advances in the understanding and treatment of human severe combined immunodeficiency. Immunol Res 2000;22:237-51.

11. Buckley RH. Pulmonary complications of primary immunodeficiencies. Paediatr Respir Rev 2004;5 (Suppl A):S225-33.

12. Lindegren ML, Kobrynski L, Rasmussen SA, Moore CA, Grosse SD, Vanderford $\mathrm{ML}$ et al. Applying public health strategies to primary immunodeficiency diseases: a potential approach to genetic disorders. MMWR Recomm Rep 2004;53:1-29

13. Fujimura MD. Níveis séricos das subclasses de imunoglobulina $\mathrm{G}$ em crianças normais e nefróticas [tese de doutorado]. São Paulo (SP): USP; 1990 